\title{
Impressions of Banana Pseudostem in Iron Slag from Eastern Africa \\ Louise lles
}

\section{Research}

\begin{abstract}
The use of banana plants in the historical iron production industries of several pre-colonial kingdoms of southern and western Uganda has been documented by the presence of banana pseudostem impressions preserved in slag, a waste product of smelting. An investigation into the selection and use of plants within these technologies was undertaken in 2003 in southern Uganda, implementing a new methodology to record the archaeobotanical information contained within the slag. Non-destructive casts of plant impressions were made on-site using a polyvinylsiloxane dental gel. These were then taken to London for further examination, and the casts were identified to the level of plant family, enabling quantitative and qualitative analysis. More recently, archaeometallurgical research in western Uganda in 2007 also revealed the repeated presence of these banana pseudostem impressions in iron smelting slag, confirming that this was an unusual, yet intentional aspect of these localized iron production technologies.
\end{abstract}

\section{Introduction}

The importance of banana plants to many of the pre-colonial kingdoms of the Great Lakes region of eastern and central Africa is undoubted and well documented (e.g., Langlands 1966, Schoenbrun 1993, Thomas 1940, Wrigley 1989). Not only were these plants extremely important as a foodstuff, it is likely that, as today, their leaves, stems and fruit were also used in many other ways. Yet, however ubiquitous, on the whole their remains do not survive well archaeologically. The means by which they are prepared for eating does not provide much opportunity for accidental carbonization (Reid 2003), and they do not produce wood or seeds, and only limited pollen (Mbida et al. 2001, Ssebuliba et al. 2006). As such, archaeological research has necessarily centred upon microbotanical remains such as phytoliths (e.g. Mbida et al. 2000 and 2001, Lejju et al. 2006), although finding secure archaeological contexts, sealed and undisturbed, often proves problematic in this region. Additionally, linguistic evidence has proved a highly valuable resource in tracing the history of the banana across Africa and specifically in the Great Lakes (e.g., Blench 2009, Schoenbrun 1993, 1998).

Recent archaeometallurgical research in Uganda has encountered an unexpected means by which to detect archaeological evidence for banana plants in this region. Since 2000, research has been carried out into the iron industries of two of the pre-colonial kingdoms of western and southern Uganda - Buganda and Bunyoro-Kitara (cf. Figure 1, Humphris 2004, Humphris et al. 2009, lles 2004, Reid 2003, Reid \& Humphris n.d., Reid \& Young 2003). A wide variety of plants played a number of essential roles in the iron production technologies of these kingdoms, fulfilling technical functions as fuels for the smelt and as packing materials for the furnace, as well as often imparting symbolic meaning as 'medicines' to ensure the success of the smelts (e.g., Roscoe 1923). The remains of these plants preserve in the archaeological record as charcoal sealed in the furnace pit, charcoal fragments

\section{Correspondence}

Louise Iles, UCL Institute of Archaeology, London, UNITED KINGDOM.

louise.iles@gmail.com

Ethnobotany Research \& Applications 7:283-291 (2009)

Published: July 30, 2009 


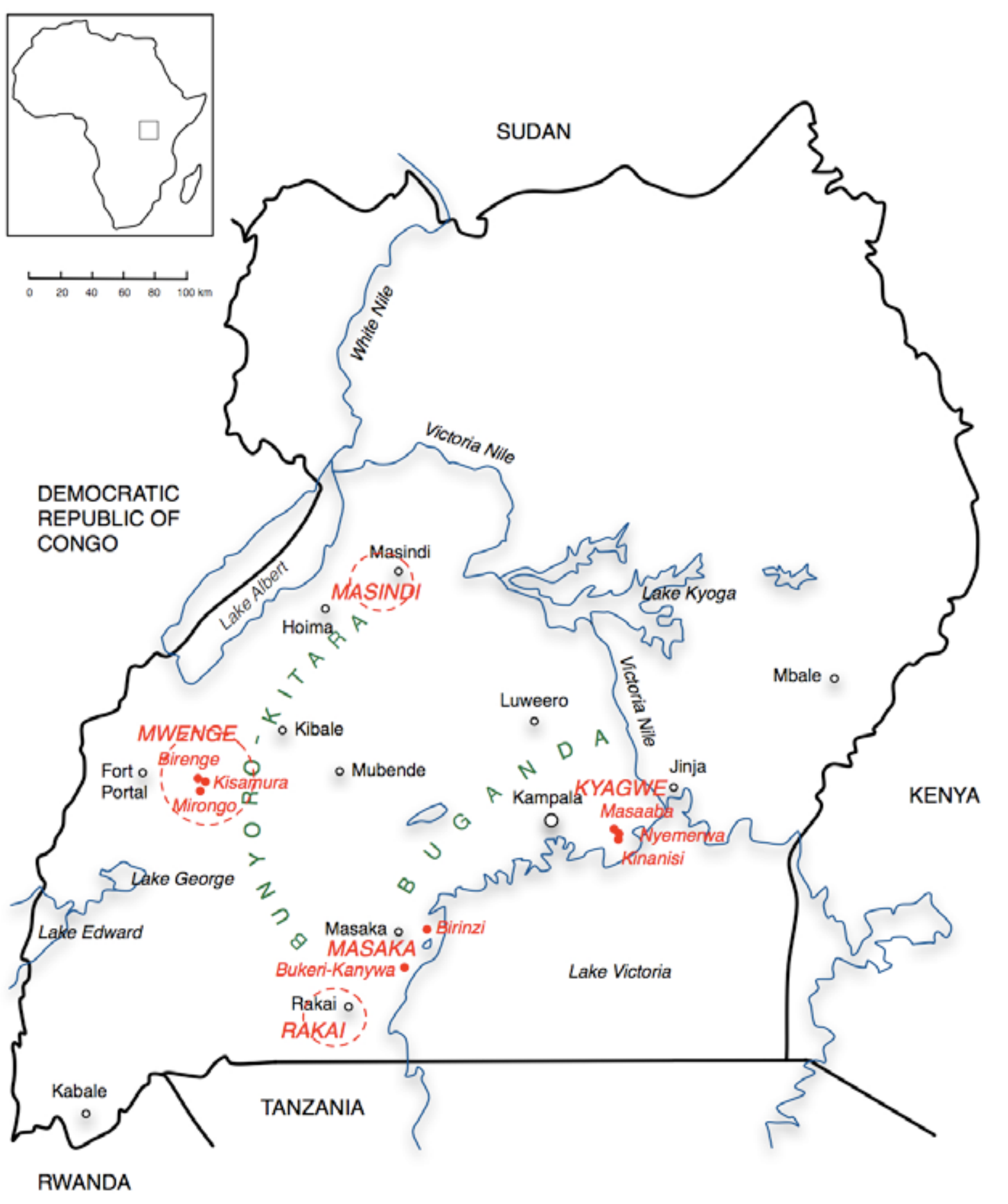

Figure 1. Some pre-colonial kingdoms (in green) and smelting areas (in red) In Uganda. 
trapped within the blocks of slag that constitute the waste product of this process, or as fossil-like impressions of the plant material preserved in such slag blocks. In several instances, as this paper will discuss, it has been possible to identify the remains of banana plants, specifically their pseudostems, in this way.

\section{The Archaeometallurgical Record}

Slag is an ideal material for metallurgical study - it preserves well in the archaeological record and it is heavy and unwieldy, meaning that people generally tend to be reluctant to move it far from its original location. It is also a valuable tool with which to reconstruct the technical aspects of individual iron production episodes, allowing for an insight into the methods and practices of past smelters.

Slag found in sub-Saharan Africa generally would have been formed as the waste product of the solid-state, bloomery method of iron smelting (Bachmann 1982, Miller \& van der Merwe 1994). During this process, iron ore and charcoal are loaded into a furnace structure (Figure 2). The furnace is lit and kept burning, air being continually introduced through a number of tuyeres and bellows. Once a temperature of around $1120^{\circ} \mathrm{C}$ is reached, far below the melting temperature of iron, the gangue materials become molten (becoming slag) and physically separate from the iron oxides within the ore; further to this, the reducing atmosphere within the furnace allows these iron oxides to chemically reduce to iron metal. The intended outcome of this process is a spongy iron bloom, which remains solid throughout.

One of the major functions of the furnace is to provide a means by which to facilitate the successful physical separation of the slag from the bloom. In a tapping furnace, the molten slag is drained away from the furnace periodically throughout the smelt, into a hollow dug beside the main furnace structure. In the case of a pit furnace, a pit is dug beneath the furnace chimney, and is generally packed with the stalks of grasses or reeds, or other rigid plant material. At the beginning of the smelt, this packing provides a base on which to build layers of the furnace charge of ore

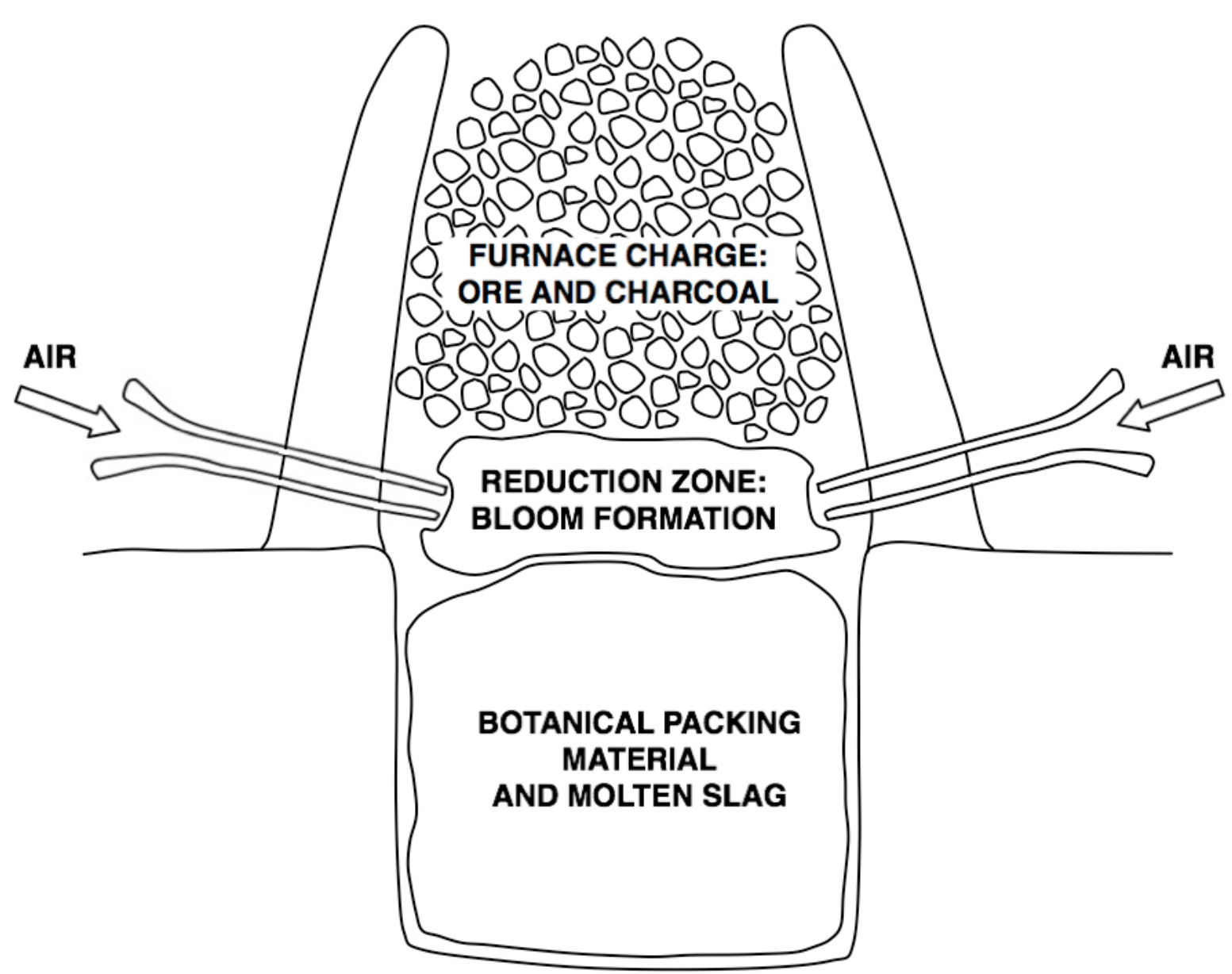

Figure 2. Schematic diagram showing the working of a slag-pit furnace. 
and charcoal. As the smelt progresses, not only does this structure allow the charge to remain in the reduction zone, but it also becomes a receptacle for the molten slag, which runs through the fill structure and cools around the pit filling (Figure 2). Impressions of the packing material are left both on the surface of, and throughout the slag as it cools and solidifies. In this way, tangible evidence of these plant materials is preserved in the slag (Figure 3). Impressions are formed not only as the slag replaces the plant matter (resulting in a positive impression), but also when the slag surrounds it (resulting in a negative impression).

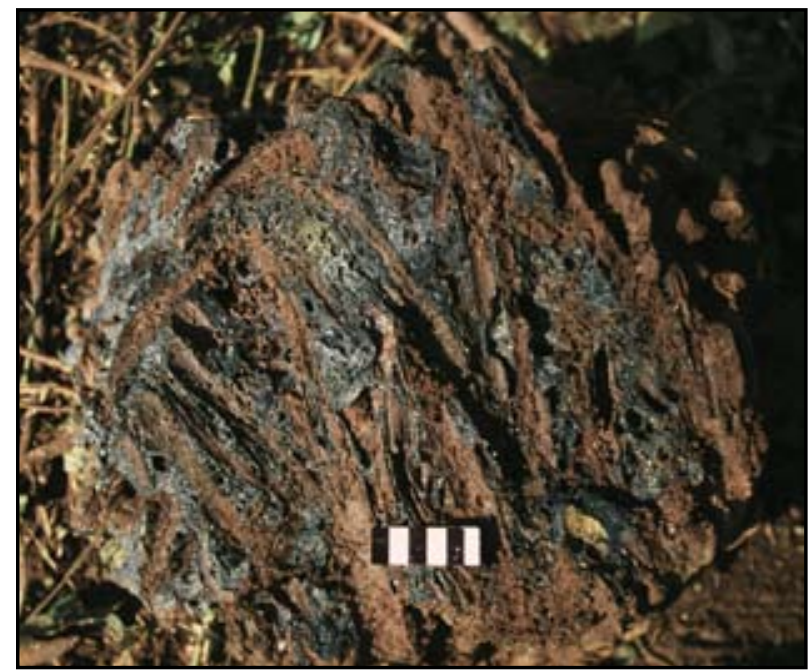

Figure 3. Plant impressions visible on a slag block from Kinanisi, Uganda (courtesy of A. Reid). Scale bar is graduated in $\mathrm{cm}$.

\section{Evidence from Buganda and Bunyoro-Kitara}

It is widely considered that iron production was a powerful force in the later histories of the Great Lakes kingdoms of Buganda and Bunyoro-Kitara, providing a strong, malleable material with which to produce weapons and agricultural tools, which were to shape the region's environment, economy and social organization. Bunyoro-Kitara was said to have been the biggest producer and trader of iron in the region, controlling as it did large areas of land containing all the necessary ingredients for successful, large-scale iron production (Connah 1996, Roscoe 1923, Tosh 1970). Buganda to the east, one of Bunyoro-Kitara's major trading partners, forcibly took control of some of these valuable resources in the eighteenth century AD (Reid 2002).

In 2000 and 2001, survey led by Andrew Reid within territory relating to the former Buganda kingdom (cf. Reid 2003), initially noted the presence of several iron production sites dominated by the presence of slag blocks bearing plant impressions, mainly of reeds and grasses (Reid \& Young 2003). Prominent, but much less frequent were slag blocks displaying the impressions of Musaceae pseu- dostems, which were found to occur only at the sites of Masaaba and Nyemerwa (Figure 1).

In order to develop a wider understanding of the full chaîne opératoire of these technologies, and to ascertain what factors had influenced the selection strategies and technological choices of past smelters, a two-pronged study was devised and implemented during fieldwork in 2003. Excavations were carried out at four smelting sites - Masaaba and Kinanisi in Kyagwe, and Bukeri-Kanywa and Birinzi in Masaka (Figure 1). Most of these sites were found to date to the eighteenth or nineteenth centuries, except the smaller-scale iron production of Bukeri-Kanywa that is believed to date to the sixteenth century (Reid \& Humphris in prep.). An archaeometallurgical study assessed the technical components of smelting at these sites (Humphris 2004, Humphris et al. 2009) and was complemented by a parallel project which aimed to investigate in more detail the variation in plant use of these technologies, directly targeting the plant impressions occurring in the slag (lles 2004 , lles in press).

Polyvinylsiloxane casts were taken of nearly 500 plant impressions across the four sites (Figure 4) and examined at the UCL Institute of Archaeology, in comparison to a reference collection of modern plant material that was also gathered during the 2003 fieldwork. It was revealed that grasses and sedges (papyrus) were used as furnace packing material in varying proportions throughout the sampled sites (for an extensive description of the applied casting methodology and the full results of the study, see Iles in press). The plant impressions at the site of Masaaba, however, presented a different picture. In this case, although the majority of the plant impressions were yet again papyrus and grasses, $3 \%$ of the impressions were of Musaceae pseudostem and $20 \%$ were dicotyledonous leaf impressions. When compared to the archaeometallurgical data, a distinctive pattern of plant use emerged at

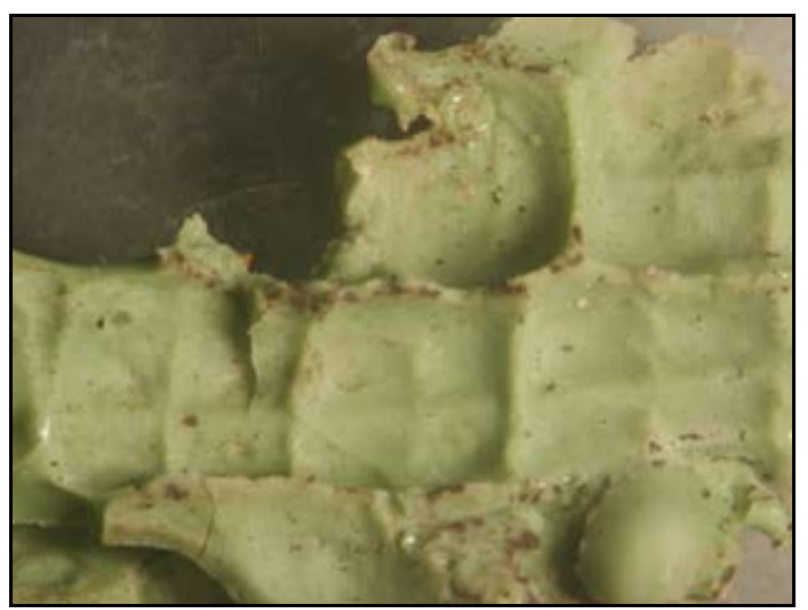

Figure 4. Polyvinylsiloxane cast of a banana pseudostem impression in slag from Masaaba, Uganda. Image width $1 \mathrm{~cm}$. 
Masaaba that corresponded with the use of a particular slag-tapping technology, in contrast to the pit furnaces utilized at the other sites.

In 2007 further archaeometallurgical fieldwork was carried out in western Uganda, investigating the iron-production industries of the pre-colonial kingdom of Bunyoro-Kitara. Survey was undertaken across three areas
However, there are several considerations that have led to the conclusion that the impressions occurring in the slag blocks resulted from the use of Musa (banana) rather than Ensete, based mainly on the relative availability of these genera during the kingdom period (Edmond De Langhe pers. comm. 2008). By the second millennium $A D$, Musa species were already well established in the region, with pockets of intensive banana farming across

- Mwenge, Masindi and Rakai - and resulted in the location of approximately 200 new sites with smelting remains including slag blocks, almost all of which displayed similar plant impressions to those previously described in neighboring Buganda. Ten of these new sites were chosen for more intensive investigation and excavation, all of which are expected to date to the late second millennium AD. More detailed descriptions of the plant impressions were recorded at these sites, although no dedicated investigation of plant use was undertaken. Three of the sites in the central Mwenge region - Mirongo, Kisamura and Birenge (Figure 1) - contained slag blocks displaying impressions of Musaceae pseudostems alongside the more commonplace grass impressions (Figures $5 \& 6$ ).

\section{Interpreting the Results}

Unfortunately, it was not possible during the course of this research to develop a methodology to discriminate Musa from Ensete based on anatomical observations of the pseudostem morphologies as preserved in the casts of the plant impressions.

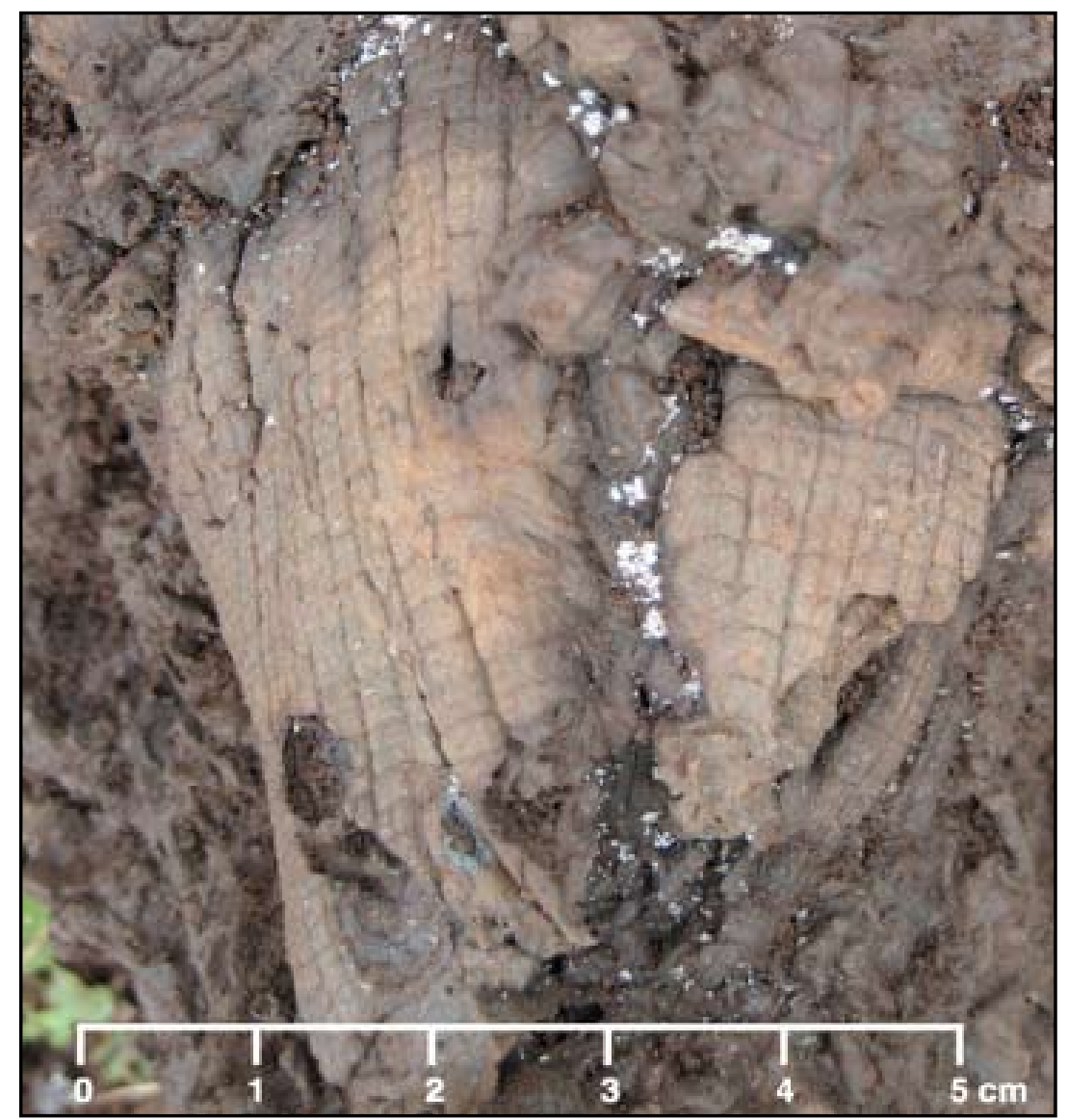

Figure 5. Musaceae pseudostem impression in slag from Birenge, Uganda.

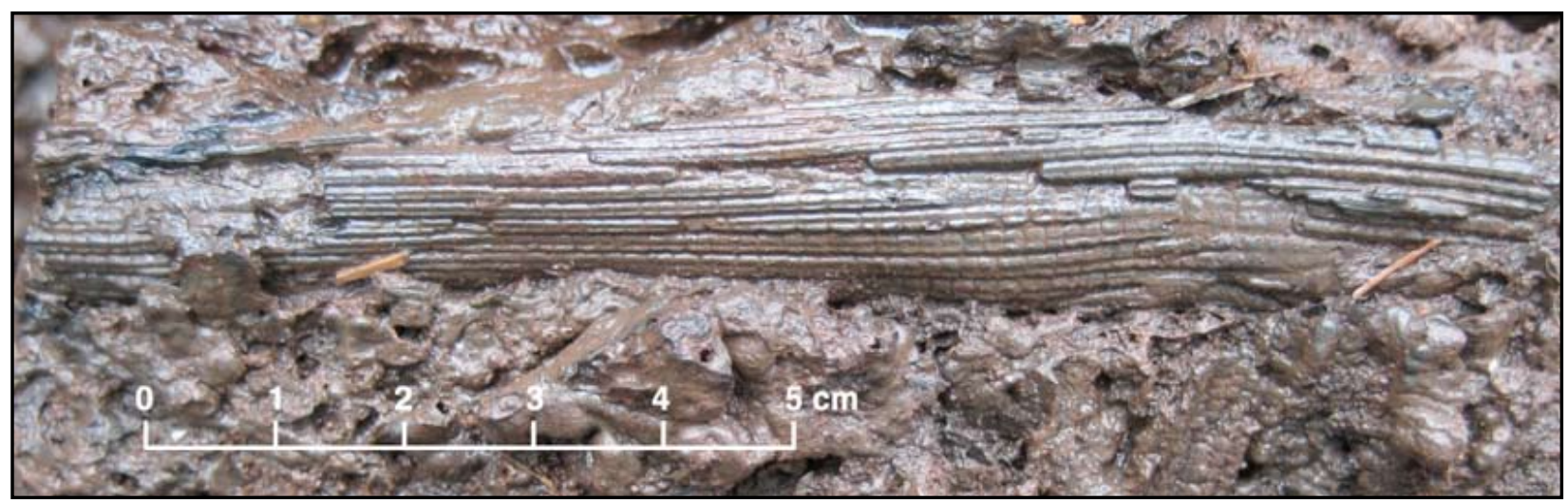

Figure 6. Musaceae pseudostem impression in slag from Birenge, Uganda. 
much of western and southern Uganda (Schoenbrun 1993, 1999). Further to this, the level of human occupation around the iron-working centers where the slag was produced would have meant that survival of significant populations of Ensete was probably minimal. As such, it is unlikely that Ensete would have been regularly available for use in these iron production technologies, contrasting strongly with the high level of availability of banana pseudostems. It might also be significant to consider that so far there has been no evidence to suggest that Musaceae was used in earlier smelting technologies, which suggests that this was a technological innovation that occurred only once bananas were freely available, or equally, once they had become culturally significant. Therefore, for the remainder of this paper, I will refer to the Musaceae impressions as banana.

Judging from the investigations carried out within both of these kingdoms, the use of banana plants within these past smelting traditions appears to be highly site-specific (cf. Table 1). In Buganda, banana pseudostem impressions were recorded at Masaaba and Nyemerwa, but not

Table 1. Uganda archaeological sites with occurrences of banana impressions.

\begin{tabular}{|l|l|c|}
\hline Region & Site & $\begin{array}{l}\text { Presence of Musaceae } \\
\text { Impressions? }\end{array}$ \\
\hline \multirow{3}{*}{ Kyagwe } & Masaaba & Yes \\
\cline { 2 - 3 } & Nyemerwa & Yes \\
\cline { 2 - 3 } & Kinanisi & No \\
\hline \multirow{3}{*}{ Masaka } & Bukeri-Kanywa & No \\
\cline { 2 - 3 } & Birinzi & No \\
\hline \multirow{3}{*}{ Mwenge } & Birenge & Yes \\
\cline { 2 - 3 } & Kisamura & Yes \\
\cline { 2 - 3 } & Mirongo & Yes \\
\hline
\end{tabular}

at nearby Kinanisi, a site less than ten kilometers away. No impressions of banana plants were recorded at all in Masaka. In Bunyoro-Kitara, banana impressions were present at Birenge, Kisamura and Mirongo but not at the three other excavated sites within a seven-kilometer radius, and not in any of the other two survey zones. The site of Mirongo is particularly interesting in this respect. Two distinct clusters of slag blocks were uncovered and examined at this site, separated by a matter of only twenty metres. However, whereas the slag blocks of one cluster were devoid of banana plant impressions, they were present at the other. The varying, perhaps idiosyncratic, use of plants may indicate the presence of a wider package of technological variations, as the presence of banana impressions corresponded with several other notable differences between the slag blocks from the two clusters, including the design of the furnaces and the ingredients used in the smelts. However, at this stage, a more defi- nite interpretation will have to await further investigation for any tenable link between technology and the use of banana plants to become apparent, although the unusual tapping strategy at Masaaba is also suggestive.

\section{The Role of Banana Plants in Smelting Activity}

Why is the banana - a common plant in this region at this time - used only in certain smelts or, indeed, used at all? The banana impressions on the slag from Buganda are solely present on the slag from slag-tapping furnaces. Perhaps this specific technology has a technical requirement for the use of banana pseudostems. One suggestion is that such plants may have been used as a means to shield the ironworkers from the hot materials emerging from the furnace. In the records of John Roscoe, an early twentieth century English missionary to the region who made in-depth observations of many of the local trades and crafts, Baganda smelters used green branches to quench the fire and protect the iron bloom as it was pulled out of the furnace (Roscoe 1911). It is possible that banana pseudostems, with their high moisture content, would have had a similar protective effect and, if they were used in such a way, this would surely have resulted in impressions forming on the surface of the slag. This explanation may also account for the presence of dicotyledonous leaf impressions on these same slag blocks. Another possibility is that the tapping pits may have been reinforced with banana pseudostems, which would have acted as a bund or wall to control the molten slag (A. Reid pers. comm. 2004), again allowing soft, malleable slag to come into contact with banana plants as it cooled.

However, the banana-impressed slag blocks from Mirongo, Kisamura and Birenge do not necessarily appear to be related to this tapping technology and so other suggestions are required to explain their presence. One suggestion posits that the impressions may not be related to the inclusion of banana pseudostems in the furnace structure at all, and could instead be associated with the use of banana plants in the production of charcoal, helping to smother the partially burned logs (Reid \& Young 2003). In a limited number of cases, fragments of banana pseudostem may have accidentally made their way into the furnace pit along with the charcoal. An alternative possibility draws on ethnographic descriptions of the smelting practices of the Barongo in Kagera in northwest Tanzania, where furnace pits are lined with unspecified leaves (Schmidt \& Childs 1985). Perhaps in western Uganda, in a way similar to Kagera smelting, the incorporation of these moisture-rich pseudostems in a furnace lining capacity may have improved the resistance of the furnace to the high temperatures endured throughout a smelt (Reid \& Young 2003). 
Finally, it is prudent to consider that any ingredients of a smelt were unlikely to have been chosen by chance. The labour-intensive nature of bloomery smelting and the high expense, if a smelt were to fail, suggest that a particular 'recipe' of successful smelting, from both technical and ritual perspectives, was probably followed time and time again. Further to this, we know that the materials used in a smelt were sometimes imbued with ritualistic notions of fertility and reproduction across sub-Saharan Africa (Barndon 2004, Childs 1991, Herbert 1993, Schmidt \& Mapunda 1997), and also that bananas were surely of significant cultural importance to these specific smelting communities. Can we link these factors to suggest that the inclusion of elements of banana plants in these technologies may have been related to increasing the fertility of the smelt and ensuring a successful outcome? This would probably be stretching the evidence too far, but an interview in 2003 with Kiwanuka Livingstone, from Gurama village near the site of Kinanisi, raised some interesting points about such plant use. Kiwanuka could trace his ancestry through a long line of smelters, and he himself had taken part in smelts (specifically utilizing pit-furnaces) when he was younger. He recalled the use of banana plants in two contexts during the smelts that he remembered, none involving the packing material for the slag pits. First, cultivated banana fibre was dipped in water and placed into the charcoal, purportedly to contain the fire of the furnace and to concentrate the heat. Secondly, a wet banana 'stick' was placed on top of the furnace in a symbolic manner (Iles 2004). Although lacking detail, this information does tantalizingly suggest that banana plants were seen to have both a technical value and a symbolic significance to the Baganda smelters operating in this area in the not-too-distant past.

\section{Applying this Evidence}

Unfortunately, all that can be confidently said at this stage is that banana plants were indeed used in some of the later iron producing traditions of this part of eastern Africa. Nevertheless, the preservation of the remains of this particular technological idiosyncrasy carries with it the potential to learn a little more about the role of bananas. Evidence for iron production in the region stretches back as far as the mid-first millennium BC (van Grunderbeek et al. 1982), so potentially this methodology could play a role in unearthing some of the earliest evidence for banana plants in eastern Africa.

Although banana impressions in iron slag have yet to be found in earlier contexts, one notable benefit could be the direct association between the banana pseudostem impressions and the smelting slag, meaning that new dating opportunities arise. Not only is it possible to radiocarbon date the charcoal sealed within the furnaces themselves and to generate thermo-luminescence ( $T L$ ) dates from the associated technical ceramics (e.g., Godfrey-Smith \& Casey 2003), in the near future it may also be possible to confidently date the slag itself. Recently, attempts have been made to use TL and optically stimulated luminescence (OSL) to directly date some of the mineral phases that commonly occur within slag blocks (Gautier 2001, Haustein et al. 2003), but these methods remain relatively untested and are still being developed and refined. Nevertheless, as yet there have been no instances of banana plant impressions recorded on any of the slag blocks associated with the iron industries of the Early Iron Age (i.e., approximately corresponding to pre-1000 AD), including even the recent investigations of early iron production in southern Rwanda (J. Humphris pers. comm. 2008).

Whether banana impressions are found in earlier ironworking contexts or not, the identification of banana pseudostems within the archaeological remains of kingdom-era iron-producing industries does greatly contribute to our understanding of the organization of production in these later periods. Such demonstration of small-scale technological variation can contribute to discussions regarding the importance of distinct and 'closed' knowledge systems often associated with smelting communities and between individual smelters (e.g., Childs 1991, Reid \& MacLean 1995). Smelting was not simply a repeated technology, but one practiced generally in seclusion and with the definite possibility of failure. Individual smelters would have been keen to acquire knowledge of any technical advantages gained by their rivals, whilst at the same time protecting, and failing to communicate, their own technological methods. This would have resulted in a patchwork of nuanced iron production technologies across the cultural landscape and in this context the subtleties of variation, including the one of banana pseudostems, is of considerable importance for the overall understanding of iron production industries at this time. As research regarding the past iron production technologies of the wider Great Lakes region continues to grow, archaeometallurgists should be encouraged to examine in more detail the extensive archaeobotanical evidence that is available to them, and to fully exploit this valuable resource to learn more about the cultural and physical environments within which these past smelters operated.

\section{Acknowledgements}

Many thanks must go to those who assisted on fieldwork in Uganda in 2003 and 2007, and especially to Meriel McClatchie and Dorian Fuller for their assistance with the botanical elements of this research. This paper is based on the dissertation that formed part of the author's Bachelors degree in Archaeology, completed at the UCL Institute of Archaeology in 2004.

\section{Literature Cited}

Bachmann, H.-G. 1982. The Identification of Slags from Archaeological Sites. Institute of Archaeology, London. 
Barndon, R. 2004. A discussion of magic and medicines in East African iron working: Actors and artefacts in technology. Norwegian Archaeological Review 37:21-40.

Blench, R. 2009. Bananas and plantains in Africa: Re-interpreting the linguistic evidence. Ethnobotany Research and Applications 7:363-380.

Childs, S.T. 1991. Style, technology and iron smelting furnaces in Bantu-speaking African. Journal of Anthropological Archaeology 10:332-359.

Connah, G. 1996. Kibiro: The Salt of Bunyoro, Past and Present. BIEA, London.

Gautier, A. 2001. Luminescence dating of archaeometallurgical slag: use of the SAR technique for determination of the burial dose. Quaternary Science Reviews 20:973980.

Godfrey-Smith, D.I. \& J.L. Casey. 2003. Direct thermoluminescence chronology for Early Iron Age smelting technology on the Gambaga Escarpment, Ghana. Journal of Archaeological Science 30:1037-1050.

Haustein, M., G. Roewer, M. Krbetschek \& E. Pernicka. 2003. Dating archaeometallurgical slags using thermoluminescence. Archaeometry 45:519-530.

Herbert, E. 1993. Iron, Gender, and Power: Rituals of transformation in African societies. Indiana University Press, Bloomington.

Humphris, J. 2004. Reconstructing a Forgotten Industry: An investigation of iron smelting in Buganda. M.A. dissertation. University College London.

Humphris, J., M. Martinón-Torres, Th. Rehren \& D.A.M. Reid. 2009. Variability in single smelting episodes - a pilot study using iron slag from Uganda. Journal of Archaeological Science 36:359-369.

Iles, L. 2004. Supporting the Smelt: An archaeological investigation into the selection and use of plants within the Buganda iron smelting tradition. B.Sc. dissertation. University College London.

Iles, L. In Press. The selection and use of plants within the iron-production technologies of Buganda. in African Flora, Past Cultures and Archaeobotany. Edited by D.Q. Fuller \& M.A. Murray. Left Coast Press, San Francisco.

Langlands, B.W. 1966. The banana in Uganda (18601920). Uganda Journal 30:39-63.

Lejju, B., P. Robertshaw \& D. Taylor. 2006. Africa's earliest bananas? Journal of Archaeological Science 33:102-113.
Mbida, C.M., H. Doutrelepont, L. Vrydaghs, R.L. Swennen, R.J. Swennen, H. Beeckman, E. De Langhe \& P. de Maret. 2001. First archaeological evidence of banana cultivation in central Africa during the third millennium before present. Vegetation History and Archaeobotany 10:1-6.

Mbida, C.M., W. van Neer, H. Doutrelepont \& L. Vrydaghs. 2000. Evidence for banana cultivation and animal husbandry during the first millennium $B C$ in the forest of southern Cameroon. Journal of Archaeological Science 27:151-162.

Miller, D. \& N. van der Merwe. 1994. Early metal working in sub-Saharan Africa: a review of recent research. Journal of African History 35:1-36.

Reid, D.A.M. 2003. Recent research on the archaeology of Buganda. Pp. 110-117 in Researching Africa's Past: New contributions from British archaeologists. Edited by P. Mitchell, A. Haour \& J. Hobart. Oxford University School of Archaeology, Oxford.

Reid, D.A.M. \& J. Humphris. n.d. Imported Iron Production Technologies and their Socio-political Incorporation in Buganda. Paper presented at 'Embedded Technologies: reworking technological studies in archaeology', May 2006, Institute of Archaeology, UCL, London. To be published in conference proceedings.

Reid, D.A.M. \& R. MacLean. 1995. Symbolism and the social contexts of iron production in Karagwe. World Archaeology 27:144-161.

Reid, D.A.M. \& R. Young. 2003. Iron-smelting and bananas in Buganda. Pp. 118-117 in Researching Africa's Past: New contributions from British archaeologists. Edited by P. Mitchell, A. Haour \& J. Hobart. Oxford University School of Archaeology, Oxford.

Reid, R. 2002. Political Power in Pre-colonial Buganda: Economy, society and welfare in the nineteenth century. James Currey, London.

Roscoe, J. 1911. The Baganda. Macmillan and Co., London.

Roscoe, J. 1923. The Bakitara or Banyoro. Cambridge University Press, Cambridge.

Schmidt, P. \& S.T. Childs. 1985. Innovation and industry during the Early Iron Age in East Africa: The KM2 and KM3 sites of northwest Tanzania. African Archaeological Review 3:53-94.

Schmidt, P. \& B. Mapunda. 1997. Ideology and the archaeological record in Africa: Interpreting symbolism in iron smelting technology. Journal of Anthropological Archaeology 16:73-102. 
Schoenbrun, D.L. 1993. Cattle herds and banana gardens: The historical geography of the western Great Lakes region, ca AD 800-1500. African Archaeological Review 11:39-72.

Schoenbrun, D.L. 1998. A Green Place, A Good Place: Agrarian change, gender and social identity in the Great Lakes region to the 15th century. James Currey, Oxford.

Schoenbrun, D.L. 1999. The (in)visible roots of BunyoroKitara and Buganda in the Lakes Region: AD 800-1300. Pp. 136-150 in Beyond Chiefdoms: Pathways to complexity in Africa. Edited by S. K. Mclntosh. Cambridge University Press, Cambridge.

Sebuliba, R., D. Talengera, D. Makumbi, P. Namanya, A. Tenkouano, W. Tushemereirwe \& M. Pillay. 2006. Reproductive efficiency and breeding potential of East African highland (Musa AAA-EA) bananas. Field Crops Research 95:250-255.
Thomas, A.S. 1940. Uganda banana varieties and their uses. Pp 116-120 in Agriculture in Uganda. Edited by J. D. Tothill. Oxford University Press, Oxford.

Tosh, J. 1970. The Northern Interlacustrine Region. Pp. 102-118 in Pre-colonial African Trade: Essays on trade in Central and Eastern Africa before 1900. Edited by R. Gray \& D. Birmingham. Oxford University Press, London.

van Grunderbeek, M.C., E. Roche, \& H. Doutrelepont. 1982. L'Age du fer ancien au Rwanda et au Burundi. Archeologie et environment. Journal des Africanistes 52:558.

Wrigley, C.C. 1989. Bananas in Buganda. Azania 24:6470. 
